\title{
Secular Stagnation in Non-EMU European Countries : Equilibrium Real Rate Approach
}

\author{
Jens Klose
}

THM Business School, Giessen, Germany

\begin{abstract}
Concerns about economies facing secular stagnation - a period of persistently lower growth - have been renewed after the start of the financial crisis in 2008 2009. This issue is well investigated for the euro area as a whole or for the individual countries forming the monetary union, with the general consensus being that secular stagnation is not present in the Economic and Monetary Union (EMU). So far no studies have been conducted for the remaining European countries, and thus this study tackles this issue for the five non-EMU European countries using the well-established LaubachWilliams model to estimate the unobservable equilibrium real interest rate and compare it with the actual real rate. The obtained results have important implications for national policymakers, i.e., if secular stagnation is present in one country, then there is a risk of growth divergence with the country's most important trading partners. The results also indicate that secular stagnation is not a significant threat to the non-EMU European countries, so they do not face structurally different growth dynamics compared with those of the euro area.
\end{abstract}

JEL Classifications: C32, E43, F45

Keywords: Equilibrium Real Interest Rate, Secular Stagnation, Non-EMU European Countries

\footnotetext{
* Corresponding Author: Jens Klose; THM Business School, Eichgaertenallee 6, 35390 Giessen, Germany, Tel: +496413094006, Fax: +496413092906, E-mail: Jens.Klose@w.thm.de.
} 


\section{Introduction}

The financial crisis of 2008 2009 influenced the economic development of almost all countries globally, resulting in lower economic growth. However, the pertinent questions to be raised are whether this decline was cyclical or structural and, accordingly, whether the countries will return to a higher level of growth or remain at a depressed level.

A theory in favor of structurally lower growth for an extended period of time- the secular stagnation hypothesis — was therefore reinvented by Summers (2014a, 2014b, 2014c). For a survey and deeper analysis of this issue, see Teulings and Baldwin (2014).

The focus of this hypothesis is the difference between the real interest rate, which is the decisive variable for investment and consumption decisions, and its equilibrium value. Summers (2014a) believes that the equilibrium real rate declined substantially in the crisis period and is now deep into the negative territory; thus, this rate is too low for the actual real rate to be reached. In this situation, secular stagnation occurs and investments and savings can no longer be balanced.

Although the equilibrium real rate is an unobservable variable, there is a straightforward way to estimate it. Laubach and Williams (2003) introduced an estimation model for the United States (US). The current study uses the same setup for five European countries that are not members of the Economic and Monetary Union (EMU). It should be noted that estimating only the equilibrium real rate does not provide any inference about whether a country is facing secular stagnation. This can only be done by comparing the equilibrium real rate with the actual real rate. In this study, this comparison is done using either the ex-ante or ex-post real rates.

While there are many studies estimating the equilibrium real rate for the euro area as a whole (Mesonnier and Renne 2007, Garnier and Wilhelmsen 2009, Belke and Klose 2013, Beyer and Wieland 2015) or for individual euro-area countries (Belke and Klose 2017), this study is the first to take a closer look at the issue of secular stagnation for five non-EMU European countries: Denmark, Norway, Sweden, Switzerland, and the United Kingdom (UK). ${ }^{1}$

Recent studies by Beyer and Wieland (2015) and Belke and Klose (2017) find that secular stagnation is not a significant threat to the euro area and its individual member

\footnotetext{
${ }^{1}$ In fact, Holston et al. (2016) also estimated the equilibrium real interest rate for the UK, besides the US, the euro area, and Canada, so the results can be compared in this case.
} 
countries. ${ }^{2}$ This has important implications for the non-EMU European countries since the euro area is the most important trading partner for all of them. If these countries face secular stagnation, then the risk of growth divergence arises, possibly leading to economic disintegration. Consider, e.g., monetary policy: Figure 1 shows the central bank policy rates of the European Central Bank (ECB) and the five central banks of the non-EMU European countries investigated in this study. It is obvious that there is a substantial degree of co-movement in the policy rates. It can be assumed that the ECB, as a large monetary union, takes the leading role in setting these interest rates, whereas the other central banks follow its lead. For Danmarks Nationalbank, this response is obvious since the Danish krone is fixed to the euro by the European Exchange Rate Mechanism.

However, if economic growth diverges between the euro area and a non-EMU country, signaling that the latter is experiencing secular stagnation, then the policy rates are also supposed to trend in different directions. While the ECB would tend to raise interest rates after returning to strong growth rates, the central bank of a secular stagnating country may prefer to leave its policy rate at the lower level or, if possible, to lower the rate even further. The result would be reflected in the exchange rate by the depreciation of the domestic currency vis-à-vis the euro.

Belke and Klose (2017) found that secular stagnation might be a problem in Greece, but in none of the other countries. Therefore, they conclude that it is a single country problem and no common monetary policy action is needed. 


\section{Figure 1. Central bank policy rates}

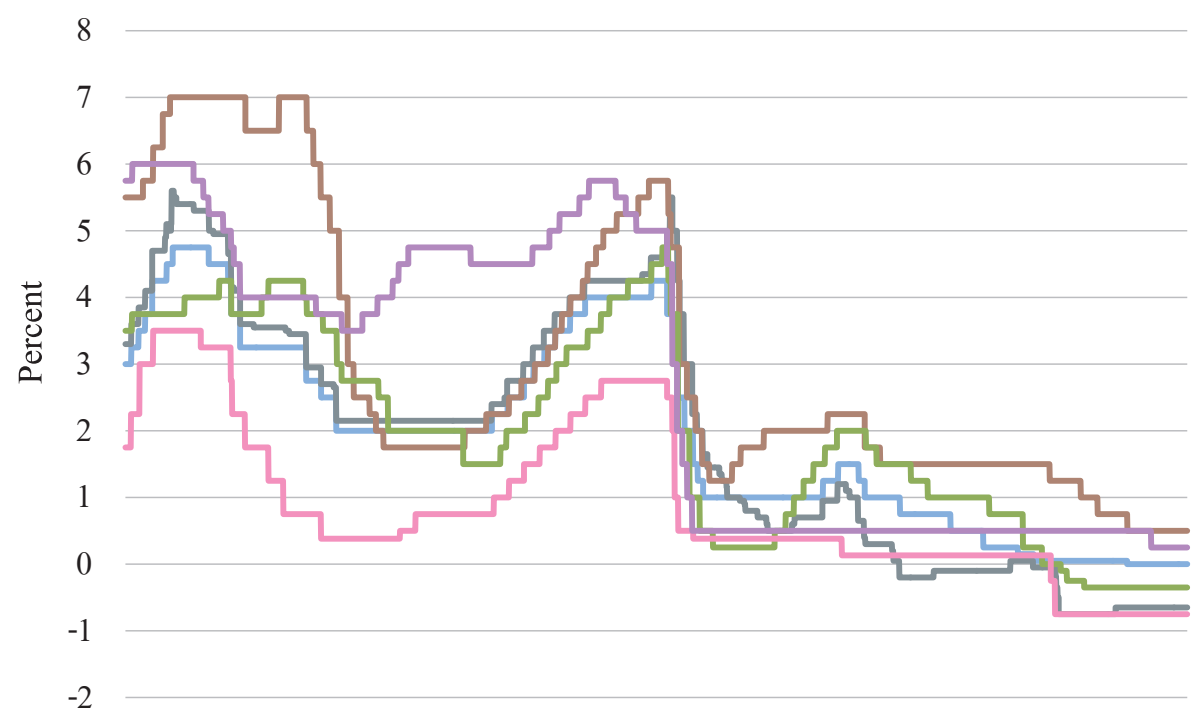

200020012002200320042005200620072008200920102011201220132014201520162017

Year

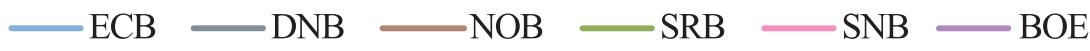

(Note) $\mathrm{ECB}=$ European Central Bank, DNB = Danmarks Nationalbank, NOB = Norges Bank, $\mathrm{SRB}=$ Sveriges Riksbank, SNB = Schweizerische Nationalbank, BOE = Bank of England.

(Source) National Central Banks.

For this reason, it is important to look at the economic situation of the non-EMU European countries separately. This paper proceeds as follows. First, the role of the real interest rate and its equilibrium value in the context of secular stagnation is explained and possible drivers of secular stagnation are discussed. Second, the data used in the empirical specifications are explained. Third, the Laubach-Williams model used to estimate the unobservable equilibrium real interest rate is illustrated. Fourth, the empirical results are presented and discussed. The final section concludes. 


\section{Equilibrium Real Interest Rates and Secular Stagnation}

The financial crisis of 2008 2009 considerably depressed output in the leading developed countries. However, even after the most severe pressures had been eased, output growth remained at persistently lower rates than those before the crisis. This phenomenon, referred to as "secular stagnation," may be explained by a permanent drop in potential output (Summers 2014a, 2014b, 2014c; Teulings and Baldwin 2014). ${ }^{3}$

The secular stagnation hypothesis focuses on the real interest rate and its equilibrium value. Under normal circumstances, both should be equalized at the point where aggregate investments equal aggregate savings. However, in a crisis period and even afterward, this may no longer be the case. The reason is quite simple: While the equilibrium real rate floats freely, the actual real rate faces a lower bound. On the one hand, the latter is due to the zero lower bound on nominal interest rates because individuals can hold excess savings in cash rather than in their bank accounts, thus generating a nominal interest rate of zero. On the other hand, inflation rates or, more precisely, inflation expectations are too low to generate significantly negative real rates. For example, inflation expectations are mainly anchored at about two percent in the countries under investigation, as this rate is the inflation target for most of the respective central banks. ${ }^{4}$

However, if the equilibrium real interest rate falls below the lower bound of the actual real rate, then there is no longer equilibrium of aggregate investments and savings (Figure 2). So, a liquidity trap via excess savings occurs (Crafts 2015). This permanently lowers a country's growth rate by reducing potential output growth (Teulings and Baldwin 2014). Note that secular stagnation is thus a structural problem that has long-term consequences, e.g., leading to permanently higher unemployment rates. While shorter periods of negative real interest rates may be tackled by expansionary monetary policy or fiscal demand-side stimulus, long-term challenges are best met by appropriate supplyside reforms.

\footnotetext{
${ }^{3}$ In fact, Summers was not the first to detect a secular stagnation. This term goes back to the 1930s when Hansen (1939) first developed this theory, in what may be considered a similar situation.

${ }^{4}$ This being said, one way to significantly lower the actual real rates is to increase the inflation target. For example, Blanchard et al. (2010) proposed increasing the target to about four percent. However, the inflation targets of the central banks in this study remain at two percent for the Bank of England and Sveriges Riksbank, less than two percent for the Schweizerische Nationalbank, below but close to two percent for Danmarks Nationalbank, and approximately 2.5 percent for Norges Bank.
} 
Figure 2. Real interest rates and secular stagnation

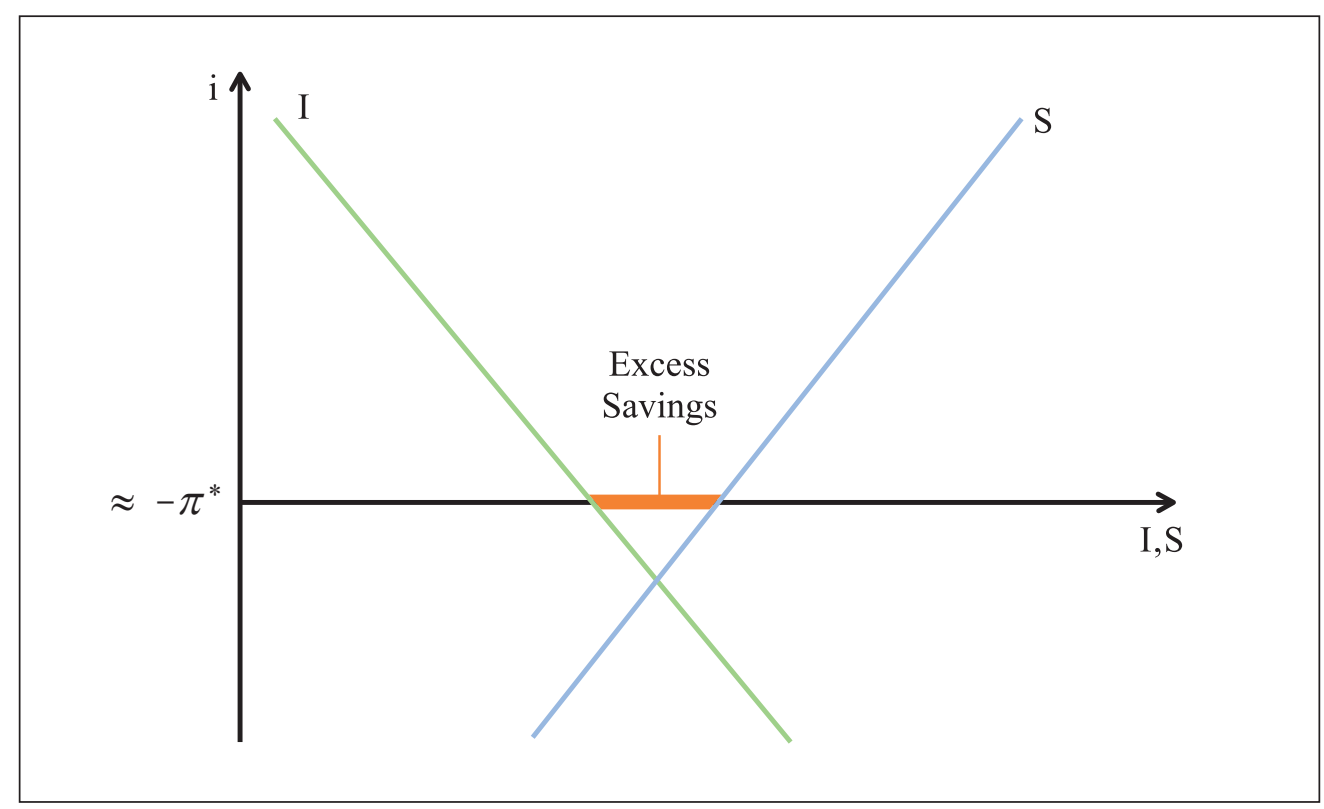

(Note) $i=$ real interest rate, $I=$ aggregate investments, $S=$ aggregate savings, $-\pi=$ central bank inflation target, approximately $-\pi^{*}$ as intercept is chosen because the minimum should be given at a zero nominal rate minus the central bank inflation target.

Along the lines of aggregate savings and investments, several determinants influencing aggregate investments, aggregate savings, or both have been discussed in the literature (Table 1).

Table 1. Determinants of aggregate savings and investments

\begin{tabular}{|c|c|c|c|}
\hline \multirow{4}{*}{ Determinants } & Savings & Effect on & Both \\
\cline { 2 - 4 } & $\begin{array}{c}\text { Preference for } \\
\text { safe assets }\end{array}$ & Innovation & Demographics \\
\cline { 2 - 4 } & Income inequality & Regulation & $\begin{array}{c}\text { Private and public } \\
\text { debt levels }\end{array}$ \\
\cline { 2 - 4 } & & $\begin{array}{c}\text { Decreasing investment } \\
\text { good prices }\end{array}$ & \\
\hline
\end{tabular}

(Note) Determinants discussed in the literature in the context of secular stagnation.

(Source) Author. 
First, preferences for safe assets have risen, especially in the wake of the financial crisis (Caballero and Farhi 2014). These safe-haven flows of capital from presumably unsafe countries into relatively safer countries also alter the aggregate savings in these countries. With respect to the non-EMU European countries, this response especially materialized in massive capital inflows since these countries were considered safe countries, leading, e.g., to the appreciation of their currencies vis-à-vis the euro if their exchange rates were not fixed to the euro, as in the case of Denmark. Another example was the fixing of the Swiss franc vis-à-vis the euro at 1.2 by the Schweizerische Nationalbank from September 2011 to January 2015. As all non-EMU European countries faced the prospect of safe asset flows to some degree, the response was to increase aggregate savings, thus lowering the equilibrium real rate in these countries.

Second, rising income inequality permanently increases savings, as individuals with high incomes have a higher marginal rate of savings (Summers 2014b). This, in turn, tends to lower the equilibrium real rate, all else being equal.

Third, a low degree of innovation, measured as increases in total factor productivity, is observed in several industrial economies. If this is the case, investments should also be low because new machinery does not generate a significant benefit in comparison to older equipment. Gordon (2014), however, believes that low total factor productivity is the new normal rather than a temporary exception, and he assumes lower growth rates on this basis. However, forecasting total factor productivity is a difficult task. Mokyr (2014) and Glaeser (2014), e.g., argue that some innovations still have the potential to boost total factor productivity, such as information technology, biotechnology, or new materials.

Fourth, a high degree of regulation in product markets may cause investments to be permanently depressed. However, these regulations can also be changed by the governing political parties. This can have a large effect (Jimeno et al. 2014, Barnes et al. 2013). The same holds with respect to labor market reforms, which tend to increase employment. Moreover, long-term unemployment leads to skill atrophy (eurosclerosis) (Blanchard and Summers 1986), thereby permanently lowering the potential rate of employment ${ }^{5}$ and potential growth (hysteresis).

Fifth, a fall in investment prices is observed, leading by construction to a downward shift in the investment curve (Summers 2014b, Glaeser 2014). These lower investment prices are simply due to the altered structure of investment goods. In a nutshell,

\footnotetext{
5 In relation to the current context, see Draghi (2014), who explicitly mentions hysteresis in unemployment when discussing the necessity of a "two-handed" approach consisting of structural reforms and expansionary macro policies.
} 
investments in IT technologies such as social networks are not as expensive as investments in industrial machinery.

Sixth, demographics are a crucial determinant, influencing both aggregate savings and investments. On the one hand, savings change according to the life-cycle hypothesis (Browning and Crossley 2001), which proposes that savings are highest in economies with a relatively large proportion of the population close to retirement. Moreover, savings may rise with increasing life expectancy and uncertainty about future pension payments, irrespective of the life cycle (Jimeno et al. 2014). On the other hand, investments fall in aging economies because revenue expectations drop when the population is about to shrink (Gros 2014). However, both channels point to a lower equilibrium real rate in aging economies.

Finally, a high degree of private and public debt depresses investment, even at low interest rates, because individuals and fiscal authorities need to consolidate. Moreover, savings are increased to reduce the level of debt. However, supporters of the secular stagnation hypothesis believe that the key to breaking the vicious circle of permanently lower growth rates is to reduce the pressure to consolidate. They tend to propose consolidation to a lesser extent and, instead, to favor increased public investment (Summers 2014a, Krugman 2014, Koo 2014).

However, whether one or several factors are, indeed, able to lower the equilibrium real interest rate to levels too low for the actual real rate to reach is mainly an empirical question. For this purpose, we employ the model most widely used in estimating the equilibrium real rate: the Laubach-Williams model.

\section{The Data}

The equilibrium real interest rate is an unobservable variable; thus, it has to be estimated. Laubach and Williams (2003) established an estimation method for this variable that employs a state-space approach. It is still the most important model used in determining the equilibrium real interest rate. Besides the unobservable equilibrium real interest rate, the unobservable potential output is also estimated in this procedure. 
The method is frequently used to estimate the equilibrium real interest rate. ${ }^{6}$ Mesonnier and Renne (2007), Garnier and Wilhelmsen (2009), Belke and Klose (2013, 2017), Beyer and Wieland (2015), and Holston et al. (2016) have also used the model to find a measure of the equilibrium real interest rate for the euro area. However, up to now, no one has applied this model to the various non-EMU European countries to account for possible disintegration within Europe. The remainder of this paper is aimed toward filling this gap.

The model is estimated with respect to five non-EMU European countries: Denmark, Norway, Sweden, Switzerland, and the UK. For two of the five countries in the sample (Denmark and the UK), we obtained quarterly data dating back to 1970. According to data availability, the sample starts in 1974 for Switzerland, 1979 for Norway, and 1982 for Sweden. All sample periods proved to be long enough to generate reliable results. The end of the sample period is 2016 Q4 for all countries under investigation.

For each of these countries, we collected data on real Gross Domestic Product (GDP), consumer prices, energy prices, and interest rates. All data are seasonally adjusted and taken from the Organisation for Economic Co-operation and Development (OECD) database. The three-month interbank rate is used as the relevant interest rate, in line with other studies in this field.

The interpretation of the results is based on a comparison of the estimated equilibrium real rate and observed real rate. For this purpose, two concepts are applied when measuring the latter rate: ex-ante and ex-post real rates. The former represents the nominal interest rate minus the expected inflation, which are adaptive expectations and thus lagged inflation rates $\left(r_{t}=i_{t}-\pi_{t-1}\right)$, whereas the latter is formulated as the interest rate minus the observed inflation rate until maturity $\left(r_{t}=i_{t}-\pi_{t}\right)^{7}$. Even though the real interest rates differ, depending on the concept used, this will only have a minor influence on the results, i.e., whether secular stagnation may be a relevant problem in a non-EMU European country.

\footnotetext{
${ }^{6}$ See, e.g., Trehan and Wu (2004), Clark and Kozicki (2005), Kiley (2015), and Laubach and Williams (2015) for the US. Holston et al. (2016) estimate the model for the US, Canada, the UK, and the euro area.

${ }^{7}$ Also see Hamilton et al. (2015) on this issue.
} 


\section{The Laubach-Williams Model}

The Laubach-Williams model consists of two signal equations and three state equations. All variables are measured as quarterly growth rates. The signal Equation (1) is an Investment and Savings (IS) curve, which measures the effect of the first two lags of the real interest rate gap $\left(r-r^{*}\right)$ on the output gap ${ }^{9}(Y-\bar{Y})$. Additionally, two lags of the output gap are added to the equation. Equation (2) is the second signal equation, which measures a Phillips curve ${ }^{10}$ and estimates the influence of the output gap on prices $(\pi)$. Moreover, the prices are assumed to vary with lagged energy prices $\left(\pi^{0}\right)$ since these are a crucial input factor in the production process. ${ }^{11}$ Again, lagged values of the dependent variable are added. In this case, and in line with Laubach and Williams (2003), we add eight lags and assume that the second to fourth and fifth to eighth lags have the same influence. Moreover, the coefficients of the lagged inflation rates are restricted to unity, in line with the aforementioned seminal paper.

$$
\begin{gathered}
Y_{t}-\bar{Y}_{t}=\alpha_{y, 1}\left(Y_{t-1}-\bar{Y}_{t-1}\right)+\alpha_{y, 2}\left(Y_{t-2}-\bar{Y}_{t-2}\right)+\frac{\alpha_{r}}{2}\left[\left(r_{t-1}-r_{t-1}^{*}\right)+\left[\left(r_{t-2}-r_{t-2}^{*}\right)\right]+\varepsilon_{1, t}\right. \\
\pi_{t}=\beta_{\pi, 1} \pi_{t-1}+\frac{\beta_{\pi, 2}}{3}\left(\pi_{t-2}+\pi_{t-3}+\pi_{t-4}\right)+\frac{1-\beta_{\pi, 1}-\beta_{\pi, 2}}{4}\left(\pi_{t-5}+\pi_{t-6}+\pi_{t-7}+\pi_{t-8}\right) \\
+\beta_{y}\left(Y_{t-1}-\bar{Y}_{t-1}\right)+\beta_{0}\left(\pi_{t-1}^{0}-\pi_{t-1}\right)+\varepsilon_{2, t} \\
\bar{Y}_{t}=\bar{Y}_{t-1}+g_{t-1}+\varepsilon_{3, t} \\
g_{t}=g_{t-1}+\varepsilon_{4, t}
\end{gathered}
$$

\footnotetext{
${ }^{8}$ The IS curve measures the influence of the interest rate on output. It is commonly assumed that output is rising with lower interest rates and vice versa because lower interest rates reduce credit costs and deposit revenues, both of which increase private consumption and investments. Thus, the coefficient $\alpha_{r}$ is expected to be negative.

${ }^{9}$ The output gap is defined as the difference in output and its unobservable potential counterpart in percent. Potential output is assumed to be the output when the economy runs at normal capacity. Thus, if the output is above the potential output and the output gap is positive, the economy tends to overheat and vice versa.

${ }^{10}$ The Phillips curve measures the response of the output gap on the inflation rate. If the output gap is positive, then the capacities tend to be overutilized and prices tend to increase because of capacity constraints and vice versa.

${ }^{11}$ Laubach and Williams (2003) also uses import prices as a variable in the Phillips curve. However, import price data for most of the countries investigated here are not available from 1970 onward. This would have shortened the sample period considerably, leading to imprecise estimates owing to low degrees of freedom. Garnier and Wilhelmsen (2009) faced the same problem when estimating the model for the euro area. Moreover, Laubach and Williams (2003) added hours worked to their Phillips curve as a robustness check. This measure is also not included here because of data availability. Again, this procedure is in line with Garnier and Wilhelmsen (2009).
} 


$$
\begin{gathered}
z_{t}=z_{t-1}+\varepsilon_{5, t} \\
r_{t}=i_{t}+\pi_{t-1} \\
r_{t}^{*}=c g_{t}+z_{t}
\end{gathered}
$$

The state equations model the time-series generating process of the two unobservable variables: potential output and equilibrium real interest rate. The potential output $\bar{Y}$ is a function of its lagged own value and its unobservable growth rate $g$, from Equation (3). The growth rate of the potential output is, in itself, a state variable following a random walk-Equation (4), as well as the last state variable $z$-Equation (5), measuring additional determinants of the equilibrium real rate, such as the time preference of households or the determinants discussed in Section II. Equation (6) and Equation (7) show how the real rate and its equilibrium value are generated. To save degrees of freedom, the inflation expectations in the real rate are modeled simply by using adaptive expectations, thus being the lagged inflation rate. This is in line with other studies estimating the equilibrium real rate for the euro area (Mesonnier and Renne 2007, Garnier and Wilhelmsen 2009, Belke and Klose 2013, 2017, Beyer and Wieland 2015). The equilibrium real rate is generated in line with Laubach and Williams (2003), representing the sum of the trend growth and any additional factors. These additional factors are restricted to having an influence of unity on the equilibrium real rate.

However, Laubach and Williams (2013) pointed out that the error terms in the state Equation (4) and Equation (5) are biased toward zero if the model is estimated in one step. This is because of the "pile-up problem" (Stock 1994). ${ }^{12}$ They therefore recommended estimating the model in sequential steps and computing the median unbiased estimator (Stock and Watson 1998) to solve the problem. This procedure is strictly applied here, and we estimate the model in four steps.

First, both signal equations are estimated separately via Ordinary Least Squares (OLS) to generate reliable starting values. Potential output is proxied by the Hodrick-Prescott filter of Y (Hodrick and Prescott 1997). In the IS equation, the real interest rate gap is omitted at this stage.

Second, the signal equations are estimated with the Kalman filter, assuming the growth rate of potential output is constant. With these results, the median unbiased

\footnotetext{
${ }^{12}$ The pile-up problem emerges when pure maximum likelihood methods tend to estimate the standard deviations equal to zero. Given that this is very likely to be the case in the random-walk Equation (4) and Equation (5), it has to be corrected for this problem.
} 
estimator is computed as $\lambda_{g}=\frac{\sigma_{4}}{\sigma_{3}}$.

This relationship is used in the third step as a starting point. Also, the real interest rate gap is added to the IS equation and the growth rate of potential output is modeled as a timevarying variable. Based on these results, the median unbiased estimator for the additional variables affecting the equilibrium real interest rate is computed as $\lambda_{\mathrm{z}}=\frac{\sigma_{5}}{\sigma_{1}} \cdot \frac{\alpha_{r}}{\sqrt{2}}$.

In the fourth and final step, the whole model is estimated via maximum likelihood, using the two signal-to-noise ratios.

The two coefficients, $\alpha_{r}$ and $c$, are restricted to lie in the range of -0.3 to 0 and 0.5 to 1.5 , respectively. These restrictions are well in line with the findings of previous studies, wherein all estimated coefficient parameters fall within these margins. Moreover, Belke and Klose (2017) included the same restriction with respect to both coefficients for the euro-area countries.

Table 2. Parameter estimates

\begin{tabular}{|c|c|c|c|c|c|}
\hline Variables & DK & NO & SV & SW & UK \\
\hline \multicolumn{6}{|l|}{ IS-curve } \\
\hline$\alpha_{y, 1}$ & $\begin{array}{c}1.56^{* * * *} \\
(0.17)\end{array}$ & $\begin{array}{c}0.16 \\
(0.27)\end{array}$ & $\begin{array}{c}1.60 * * * \\
(0.16)\end{array}$ & $\begin{array}{c}1.38 * * * \\
(0.17)\end{array}$ & $\begin{array}{c}1.70 * * * \\
(0.05)\end{array}$ \\
\hline$\alpha_{y, 2}$ & $\begin{array}{c}-0.63 * * * \\
(0.16)\end{array}$ & $\begin{array}{c}0.13 \\
(0.14)\end{array}$ & $\begin{array}{c}-0.70 * * * \\
(0.16)\end{array}$ & $\begin{array}{c}-0.43^{* *} \\
(0.17)\end{array}$ & $\begin{array}{c}-0.75^{* * *} \\
(0.05)\end{array}$ \\
\hline$\alpha_{r}$ & $\begin{array}{c}-0.15 * * \\
(0.07)\end{array}$ & $\begin{array}{c}-0.16^{* * *} \\
(0.03)\end{array}$ & $\begin{array}{l}-0.16 \\
(0.15)\end{array}$ & $\begin{array}{l}-0.16 \\
(0.15)\end{array}$ & $\begin{array}{l}-0.15 \\
(0.14)\end{array}$ \\
\hline$c$ & $\begin{array}{c}0.84 \\
(1.41) \\
\end{array}$ & $\begin{array}{c}1.43 * * * \\
(0.27)\end{array}$ & $\begin{array}{c}1.50 * * * \\
(0.35)\end{array}$ & $\begin{array}{c}1.25 \\
(1.50) \\
\end{array}$ & $\begin{array}{c}1.43 \\
(0.37) \\
\end{array}$ \\
\hline \multicolumn{6}{|l|}{ Phillips curve } \\
\hline$\beta_{\pi, 1}$ & $\begin{array}{c}0.17 * * * \\
(0.05)\end{array}$ & $\begin{array}{c}0.54 * * * \\
(0.11)\end{array}$ & $\begin{array}{c}0.52 * * * \\
(0.08)\end{array}$ & $\begin{array}{c}0.60 * * * \\
(0.10)\end{array}$ & $\begin{array}{c}0.57 * * * \\
(0.05)\end{array}$ \\
\hline$\beta_{\pi, 2}$ & $\begin{array}{c}0.45 * * * \\
(0.08)\end{array}$ & $\begin{array}{c}0.24 * * \\
(0.11)\end{array}$ & $\begin{array}{c}0.25 * * \\
(0.10)\end{array}$ & $\begin{array}{c}0.17 \\
(0.13)\end{array}$ & $\begin{array}{c}0.24 * * * \\
(0.07)\end{array}$ \\
\hline $1-\beta_{\pi, 1}-\beta_{\pi, 2}$ & 0.48 & 0.22 & 0.23 & 0.23 & 0.19 \\
\hline$\beta_{y}$ & $\begin{array}{c}0.06^{* *} \\
(0.03)\end{array}$ & $\begin{array}{c}0.00 \\
(0.06)\end{array}$ & $\begin{array}{c}0.05 \\
(0.04)\end{array}$ & $\begin{array}{c}0.01 \\
(0.01)\end{array}$ & $\begin{array}{c}0.03 * \\
(0.02)\end{array}$ \\
\hline$\beta_{0}$ & $\begin{array}{c}-0.39 * * * \\
(0.13)\end{array}$ & $\begin{array}{c}-0.34 * * \\
(0.16)\end{array}$ & $\begin{array}{l}-0.23 \\
(0.16)\end{array}$ & $\begin{array}{c}-1.87 * * * \\
(0.10)\end{array}$ & $\begin{array}{c}-0.45^{* * *} \\
(0.16)\end{array}$ \\
\hline
\end{tabular}


(continued)

\begin{tabular}{|c|c|c|c|c|c|}
\hline Variables & DK & NO & SV & SW & UK \\
\hline Variance & & & & & \\
\hline$\sigma_{1}$ & 0.0127 & 0.7918 & 0.1186 & 0.3065 & 0.0000 \\
\hline$\sigma_{2}$ & 0.4183 & 0.2722 & 0.3111 & 0.1545 & 0.5719 \\
\hline$\sigma_{3}$ & 1.0907 & 0.0001 & 0.5094 & 0.0001 & 0.6482 \\
\hline$\sigma_{4}$ & 0.0012 & 0.0000 & 0.0000 & 0.0000 & 0.0003 \\
\hline$\sigma_{5}$ & 0.0001 & 0.0001 & 0.0002 & 0.0042 & 0.0000 \\
\hline$\lambda_{g}$ & 0.0330 & 0.0476 & 0.0006 & 0.0006 & 0.0231 \\
\hline$\lambda_{z}$ & 0.0006 & 0.0006 & 0.0006 & 0.0006 & 0.0006 \\
\hline $\log -$ likelihood & -440.17 & -334.41 & -278.76 & -205.82 & -431.69 \\
\hline
\end{tabular}

(Note) (i) ML estimation; $\mathrm{DK}=$ Denmark, $\mathrm{NO}=$ Norway, $\mathrm{SV}=$ Sweden, $\mathrm{SW}=$ Switzerland, UK $=$ United Kingdom.

(ii) $\alpha_{y, 1}, \alpha_{y, 2}$ response to lagged output gaps, $\alpha_{r}$ response to the real rate gap, $c$ response of potential output growth, $\beta_{\pi, 1}, \beta_{\pi, 2}, 1-\beta_{\pi, 1}-\beta_{\pi, 2}$ response to lagged inflation, $\beta_{y}$ response to the output gap, $\beta_{0}$ response to energy price inflation, $\sigma_{1}$ to $\sigma_{5}$ standard deviations of Equations (1) to (5), $\lambda_{g}, \lambda_{z}$ signal-to-noiseratios.

(iii) Standard errors in parenthesis; ***/**/* means significance at the $1 \% / 5 \% / 10 \%$ level.

Our results (Table 2$)^{13}$ indicate that these restrictions are generally valid since none of the estimated coefficients hit the boundary set. With respect to $\alpha_{r}$, the influence of the real interest rate gap on output, the point estimates are from -0.15 to -0.16 and they are very stable for the various countries. However, these coefficients are found to be significantly different from zero for only Denmark and Norway. Concerning parameter $c$, the influence of potential growth on the equilibrium real rate, we find significant estimates for Norway and Sweden. Moreover, the point estimates vary widely, with a range of 0.84 to 1.50 . The median unbiased estimators $\lambda_{g}$ are generally in line with the estimates for other countries in previous studies. The estimates of $\lambda_{z}$, however, are slightly lower. ${ }^{14}$ But the remaining parameter estimates and variances are well in line with other studies in this field. Thus, it can be concluded at this stage that the parameter

\footnotetext{
${ }^{13}$ Only the final estimates of the fourth step are presented here. The results for the previous steps are available from the authors upon request.

${ }^{14}$ Note that the median unbiased estimator is explicitly estimated. To date, other studies in this field (Mesonnier and Renne 2007, Garnier and Wilhelmsen 2009, Beyer and Wieland 2015) had to restrict this coefficient to obtain reasonable results.
} 
estimates are generally comparable to other studies.

\section{Results}

In this section, the estimation results of the model for the unobservable equilibrium real interest rate are presented and compared with the observed real interest rates.

As in Laubach and Williams (2003), the results for the unobserved variables are presented using a one-sided (predicted) measure and a two-sided (smoothed) version. One-sided estimates only use the data prior to the respective points in time, whereas the two-sided version uses data from the whole sample period. Although the estimated time series differ, depending on which method is used, the policy implications remain the same for both indicators. The results are shown separately for the unobserved state variables, starting with the potential output/output gap, before turning to the ex-ante and ex-post equilibrium real interest rates.

\section{A. Output gap}

The estimates of the output gap, starting mostly in the 1970s, are given in Figure 3. Rather than commenting in detail on the results for the whole sample period, ${ }^{15}$ the analysis is restricted to the recent financial crisis period beginning in 2008 2009. Note, moreover, that the results do not depend on whether a one-sided or two-sided approach is chosen but that the estimations are fairly robust across specifications.

\footnotetext{
${ }^{15}$ Note that the estimates are generally in line with those of the international organizations that used a production function approach (see, e.g., the AMECO database of the European Commission).
} 
Figure 3. One- and two-sided output gap estimates
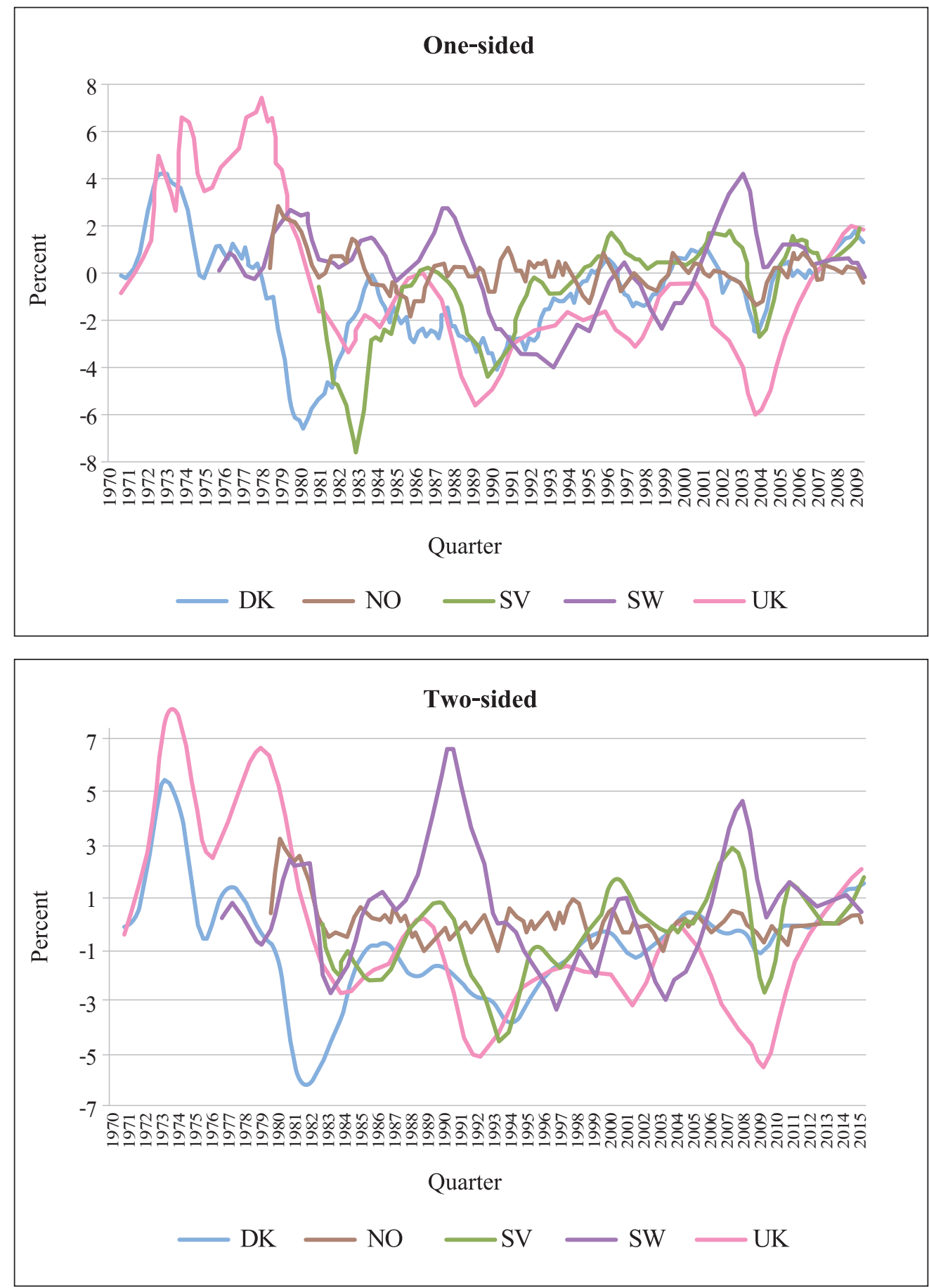

(Note) One-sided $=$ predicted estimates, two-sided $=$ smoothed estimates; $\mathrm{DK}=$ Denmark, NO $=$ Norway, $\mathrm{SV}=$ Sweden, $\mathrm{SW}=$ Switzerland, $\mathrm{UK}=$ United Kingdom. 
Obviously, 2008 marks a turning point in the output gaps of all countries under investigation because they all experienced a somewhat severe drop. With the exception of Switzerland, which had the largest positive output gap before the financial crisis, all output gaps turn negative in this period.

However, all countries exhibit a rebound in their output gap in 2010. At the end of the sample period, the output gaps are either closed (Norway and Switzerland) or positive, at about two percent (Denmark, Sweden, and the UK).

\section{B. Ex-ante real interest rates}

We now compare the ex-ante real interest rates and their equilibrium values. Figure 4 shows the one-sided estimates. Even though the results for some countries may differ, we find major similarities across countries. First, ex-ante real interest rates were much higher in the last century, especially in the 1980s, and they declined after the mid-1990s in most countries.

\section{Figure 4. Ex-ante real rates and one-sided equilibrium estimates}

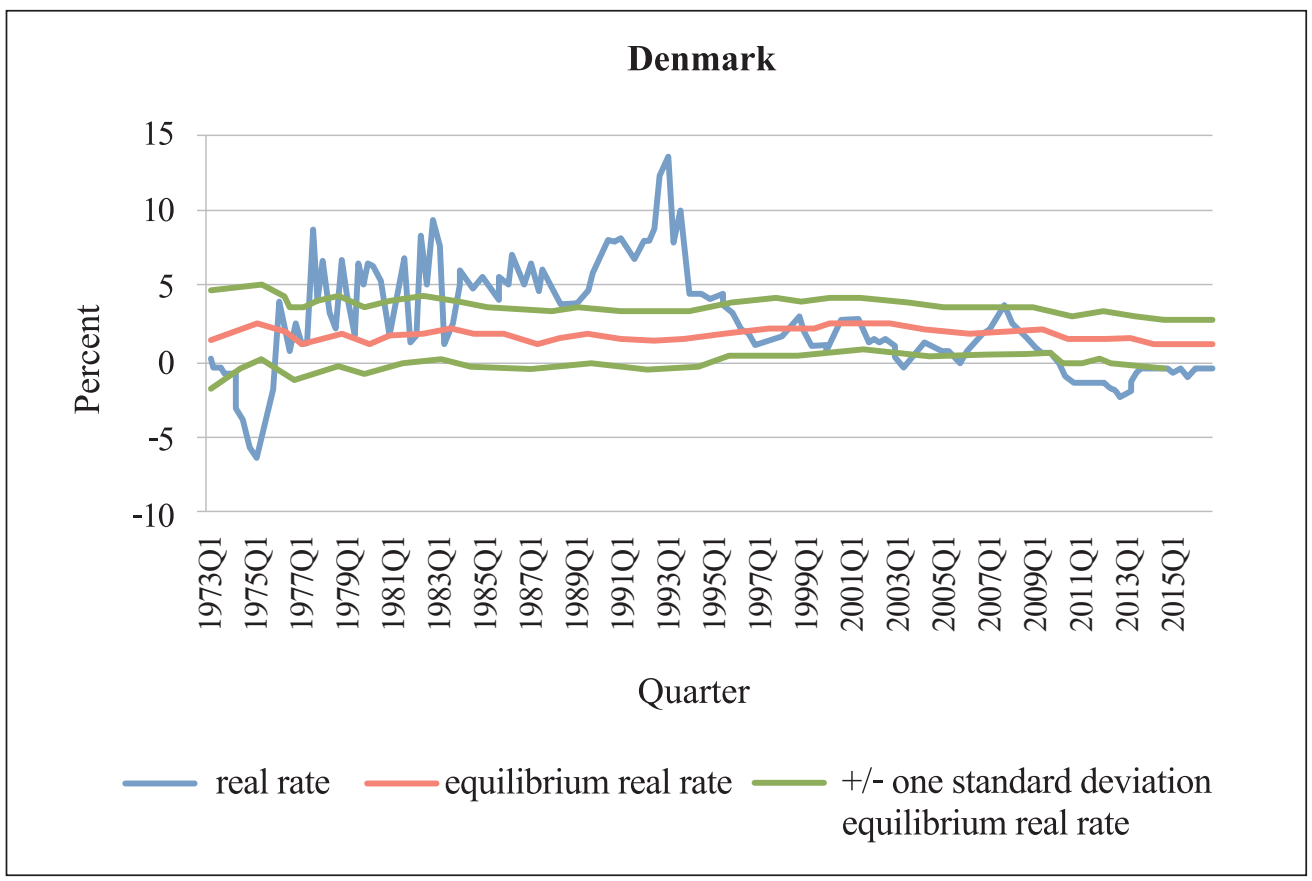



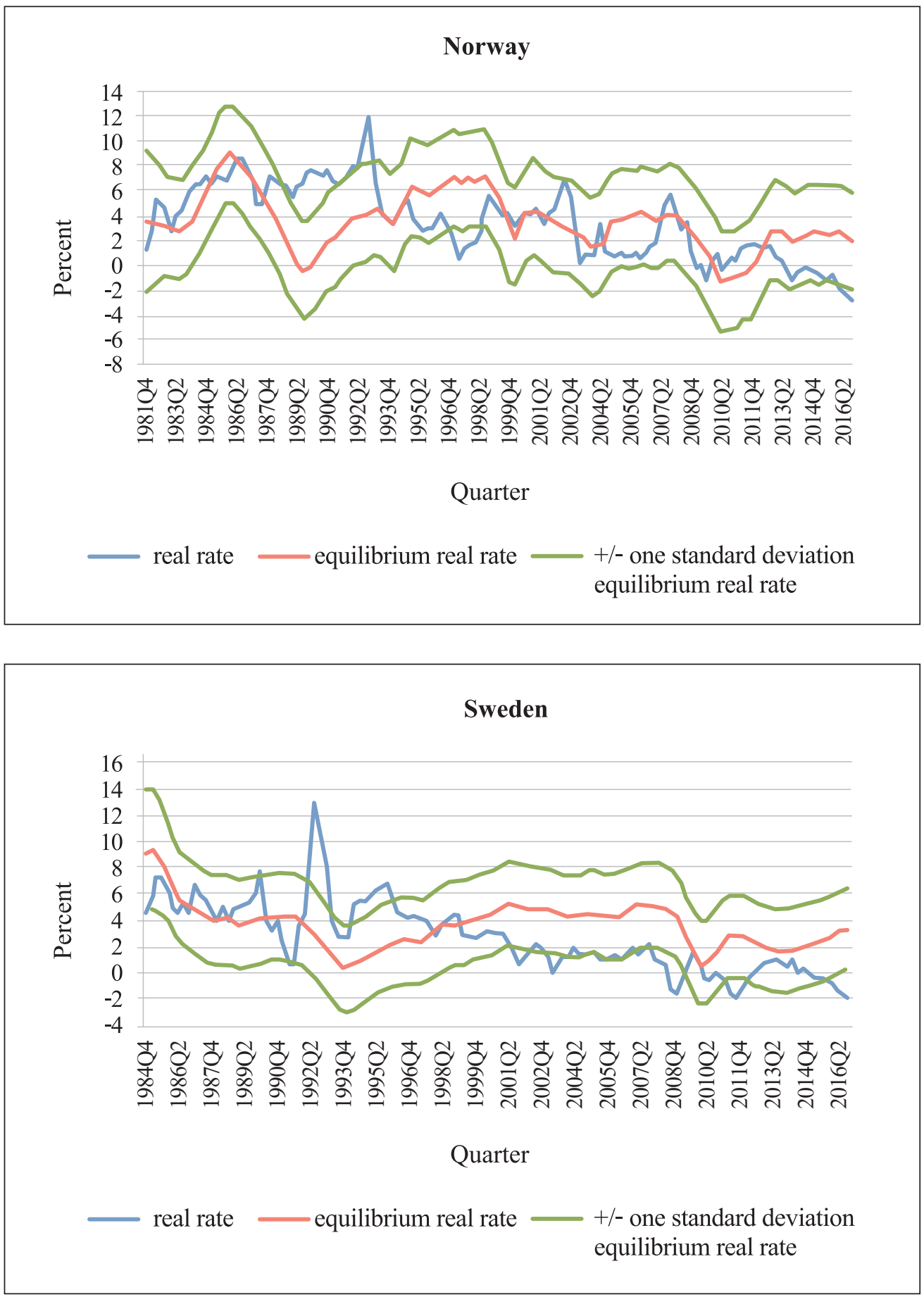

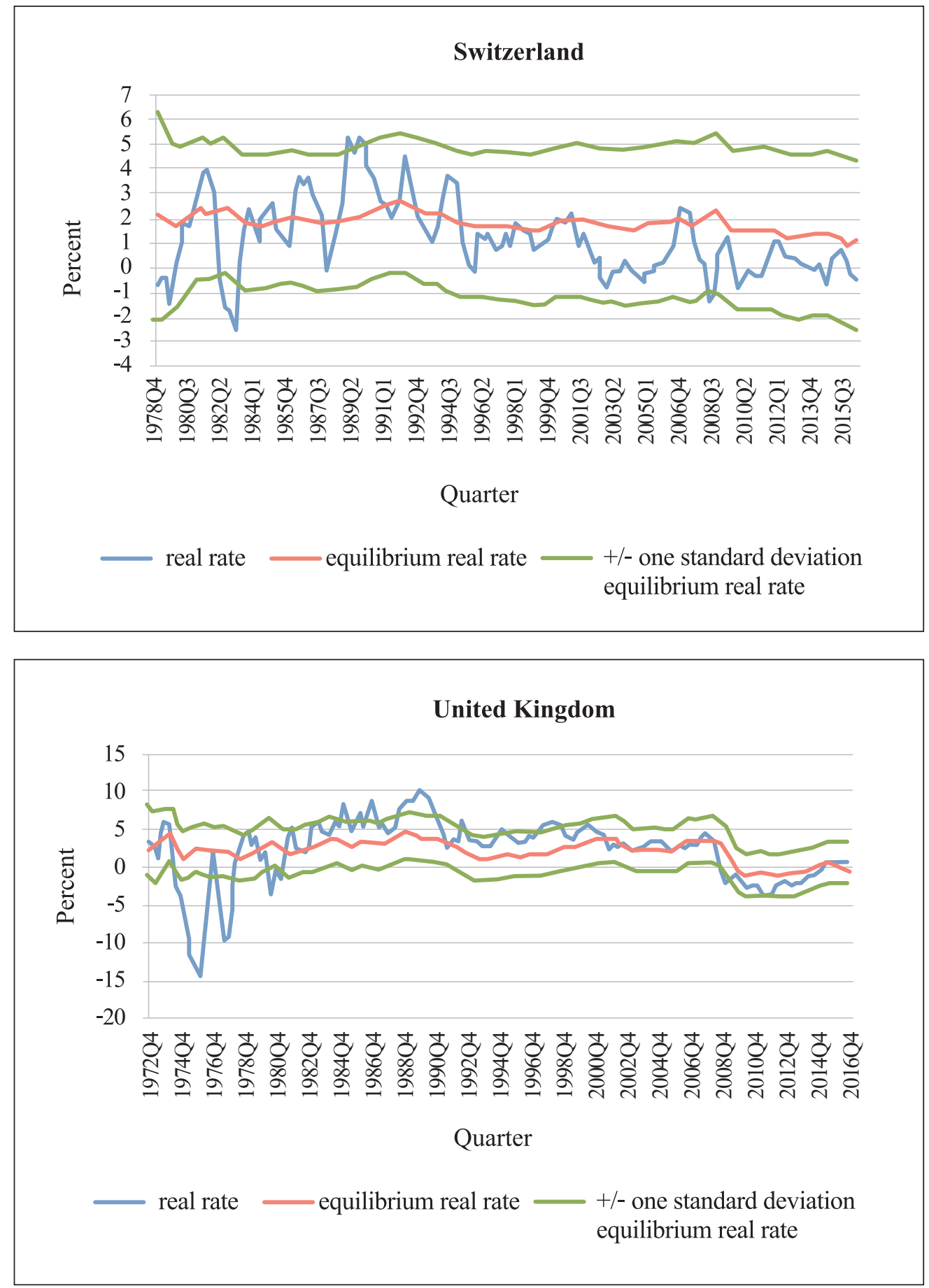
Second, in the wake of the 2008 2009 financial crisis, real interest rates became negative for all countries, at least in some quarters. The lowest real interest rate was about -3.6 percent at the end of 2011 in the UK, so it even exceeded the empirical lower bound, as indicated in Section II. At the end of the sample period, real interest rates are in negative territory for all countries under investigation. However, negative real interest rates were not rare during the history of the countries under investigation. In particular, negative real interest rates were frequently present in the 1970s, reaching a minimum of about -15 percent in the UK.

Third, in terms of the equilibrium real interest rate, the overall trend of low rates in the 1970s, higher rates in the 1980s and early 1990s, and declining rates thereafter is less clear. Over the sample period, the equilibrium real rate is much less volatile than the actual real rate in all countries, which is unsurprising since the equilibrium rate should only change if there are fundamental changes in the economy. Nevertheless, the equilibrium real rates seem to exhibit a declining trend in all countries.

Two country groups can be identified concerning the equilibrium real interest rate. The first group, comprising Denmark and Switzerland, has rather robust equilibrium real interest rates. For Denmark, the highest equilibrium rate is about 2.5 percent in 1975 and the lowest is about 1.1 percent at the end of the sample period. For Switzerland, the corresponding numbers are about 2.6 percent in 1992 and 1.0 percent in 2016. So, in both countries, the equilibrium real rate was never even close to negative territory. But note that even for these two countries, the equilibrium real rate exhibits a negative trend.

The second group, consisting of Norway, Sweden, and the UK, are found to have more time-varying equilibrium real interest rates. The highest equilibrium real rates for these countries are about 8.9 percent in 1986, 9.4 percent in 1985, and 4.3 percent in 1989 , respectively. The lowest numbers for two of these countries are even negative, at -1.3 percent in 2010 for Norway and at -1.1 percent in 2013 for the UK. ${ }^{16}$ Sweden is the only country whose minimum equilibrium real rate remains positive, at approximately 0.3 percent. Moreover, this minimum was reached in 1993, so Sweden is the only case in which the lowest equilibrium real rate was not reached during the period of the financial crisis. The lowest equilibrium real rate for Sweden during the crisis was about 0.7 percent. For this second group of countries, the drop in the equilibrium real interest

\footnotetext{
${ }^{16}$ Holston et al. (2016) also found a sharp decline in the equilibrium real rate for the UK. However, their lowest estimate remains at about 1.5 percent, which is clearly in positive territory. But they noted that their estimates for the UK are rather imprecise. This outcome is also reflected in the current study because the confidence bands are quite wide. Nevertheless, our estimates appear to be more robust, possibly because of our coefficient restrictions, as shown by the point estimates in Table 2 .
} 
rate associated with the beginning of the financial crisis is clearly visible. However, in all of these countries, the equilibrium real interest rates have recently recovered from their lowest levels.

When it comes to the question as to whether the non-EMU European countries face secular stagnation, a comparison of the actual and the equilibrium real interest rates must be made. While there are several periods in which the equilibrium real rate is below the actual real rate in almost all countries, this was not the case during the most recent financial crisis. During the crisis, there was no evidence of secular stagnation in these countries. The equilibrium real rate was slightly lower than the actual rate on only a few occasions for all countries. Therefore, drawing the inference that there is a problem of secular stagnation in these countries on the basis of a few instances is clearly wrong, especially when considering the rather large uncertainty in the estimations of the equilibrium real interest rate, as given by the one standard deviation band. ${ }^{17,18}$ So, all in all, we have to conclude from our analysis that even though the equilibrium real interest rates fell during the most recent crisis period, the actual real rates fell even further, so none of the non-EMU European countries faced secular stagnation.

When smoothing the results using a two-sided filter, the results do not change significantly (Figure 5). The only difference is that the estimates of the equilibrium real rate are even less volatile, which is exactly what is expected when the time series are smoothed.

\footnotetext{
${ }^{17}$ The standard deviation of the equilibrium real rate is computed as $\sigma_{r^{*}}=\sqrt{c^{2} \sigma_{4}^{2}+\sigma_{5}^{2}}$, which is in line with Laubach and Williams (2003). Since these calculations only represent quarterly standard deviations, four of them are summed to represent the yearly standard deviations shown in the figures.

${ }^{18}$ Several other studies face similar estimation problems with respect to the sconfidence bands in the equilibrium real rate estimations (see, e.g., Mesonnier and Renne 2007, Garnier and Wilhelmsen 2009, Beyer and Wieland 2015, Belke and Klose 2017). This is possibly because of the relatively simple modelling of the equilibrium real rate as the growth in potential output and additional factors. In particular, the latter should be modelled more explicitly by using indicators of the determinants discussed in Section II.
} 
Figure 5. Ex-ante real rates and two-sided equilibrium estimates
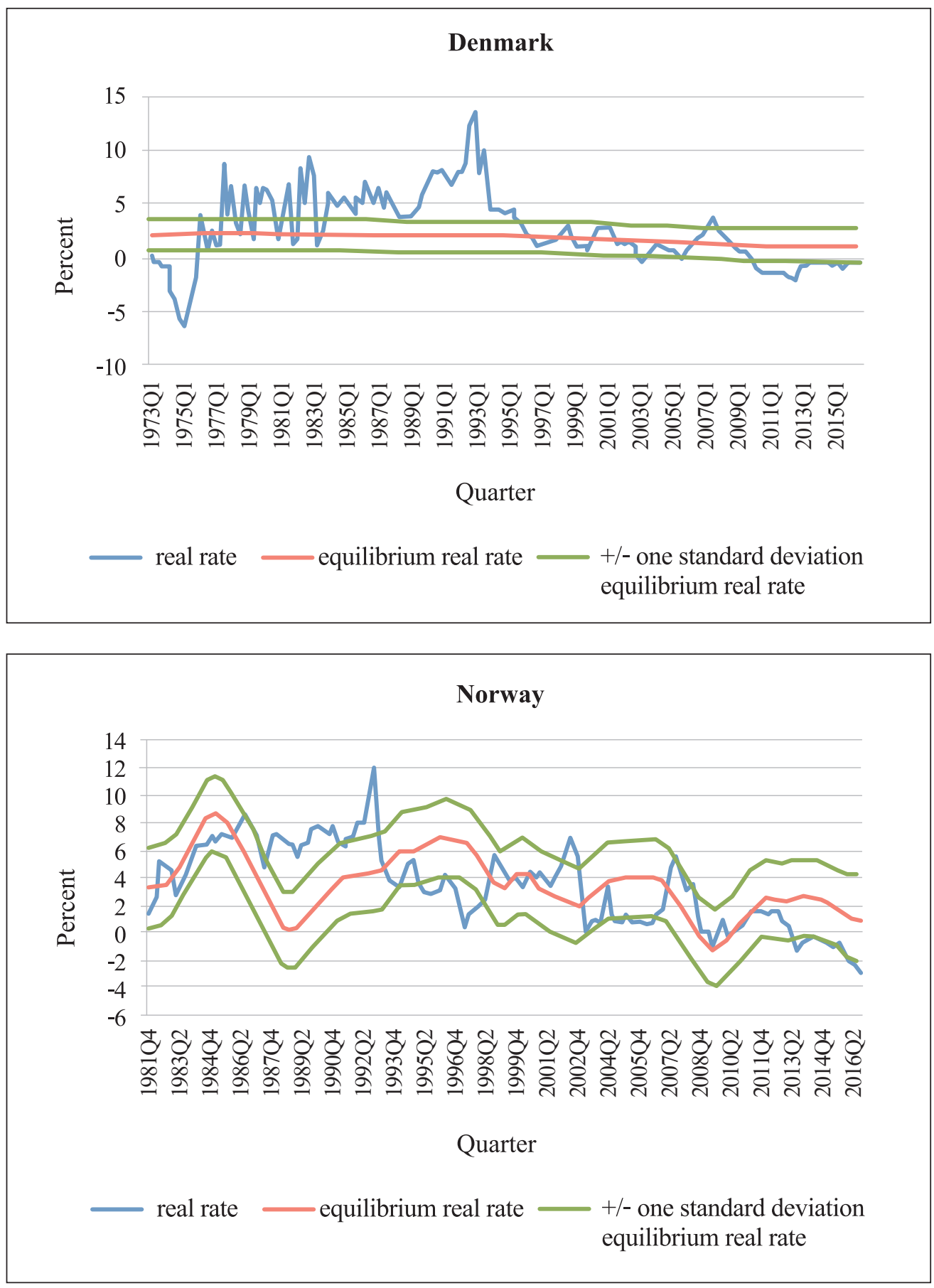

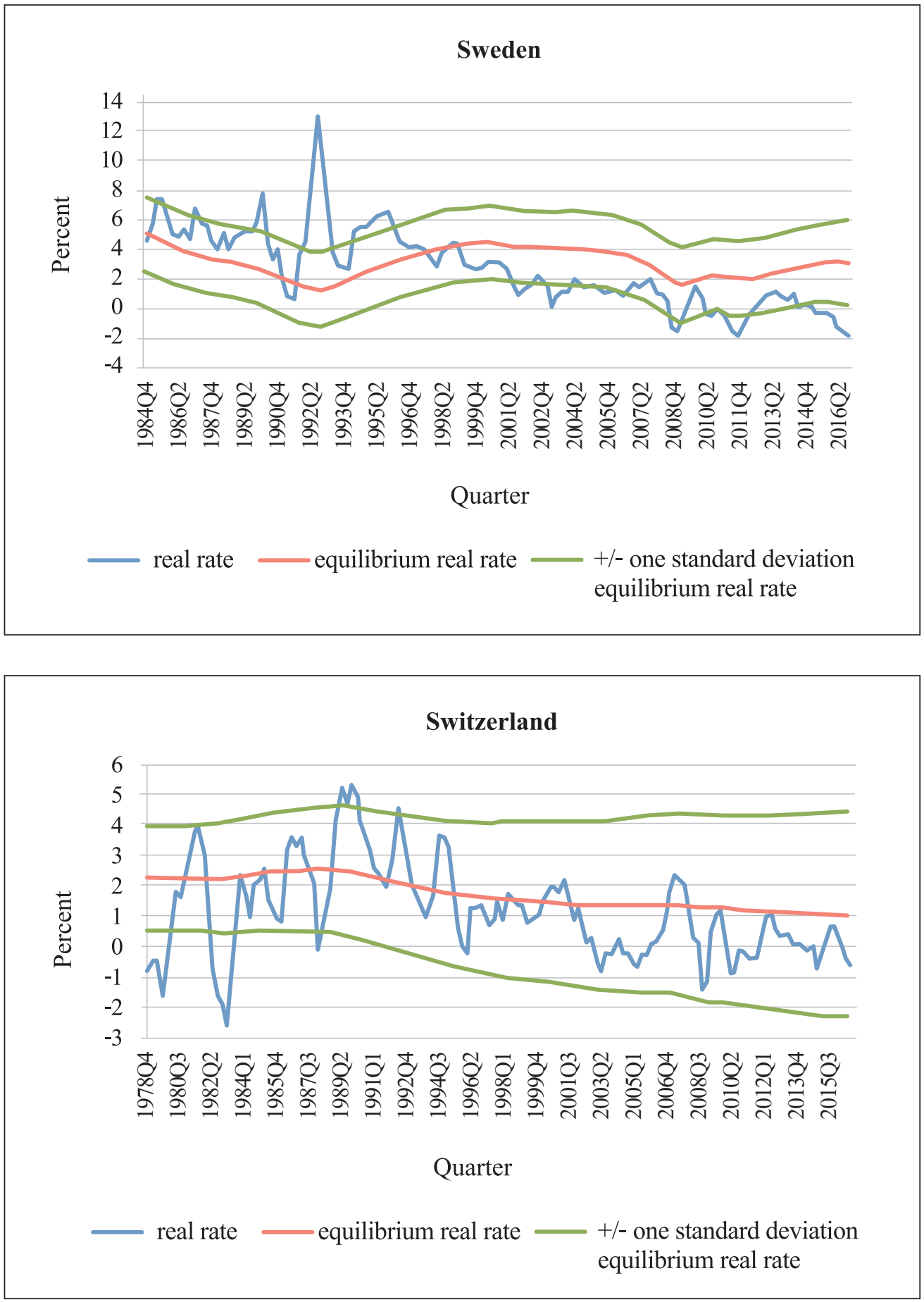


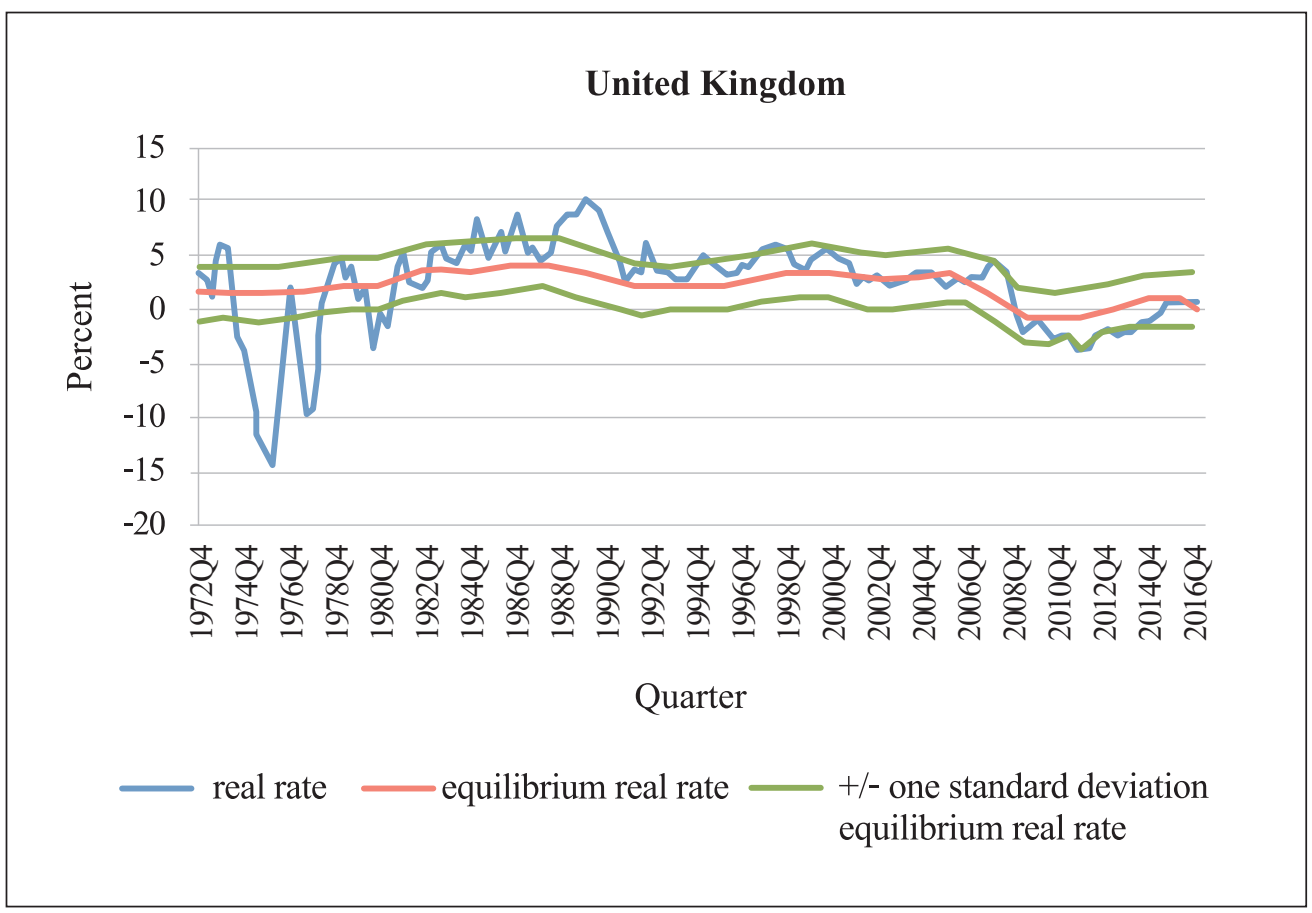

Hence, the conclusion drawn above remains valid. Secular stagnation is not a problem for the remaining non-EMU European countries because the real rates are, in fact, even lower than the equilibrium real interest rates during the financial crisis period.

\section{Ex-post real interest rates}

When employing ex-post realized real interest rates instead of ex-ante rates, the estimates for the equilibrium rates remain almost unchanged. More precisely, they only shift backward by four quarters, but the estimates themselves remain the same (see Figure 6 for the one-sided time series and Figure 7 for the two-sided estimates). However, the empirical realizations of the real interest rates might be different. While the values are indeed altered, as compared with the ex-ante data, the overall results remain robust. There are still three phases of real interest rate developments over time; namely, low and negative rates in the 1970s, high and positive rates in the 1980s and early 1990s, and declining rates thereafter, leading to below-zero values during the most recent crisis period for all countries under investigation. This being said, the main conclusion remains 
unchanged in comparison to that derived in the previous subsection. There is no evidence of secular stagnation for any of the non-EMU European countries under investigation.

Figure 6. Ex-post real rates and one-sided equilibrium estimates

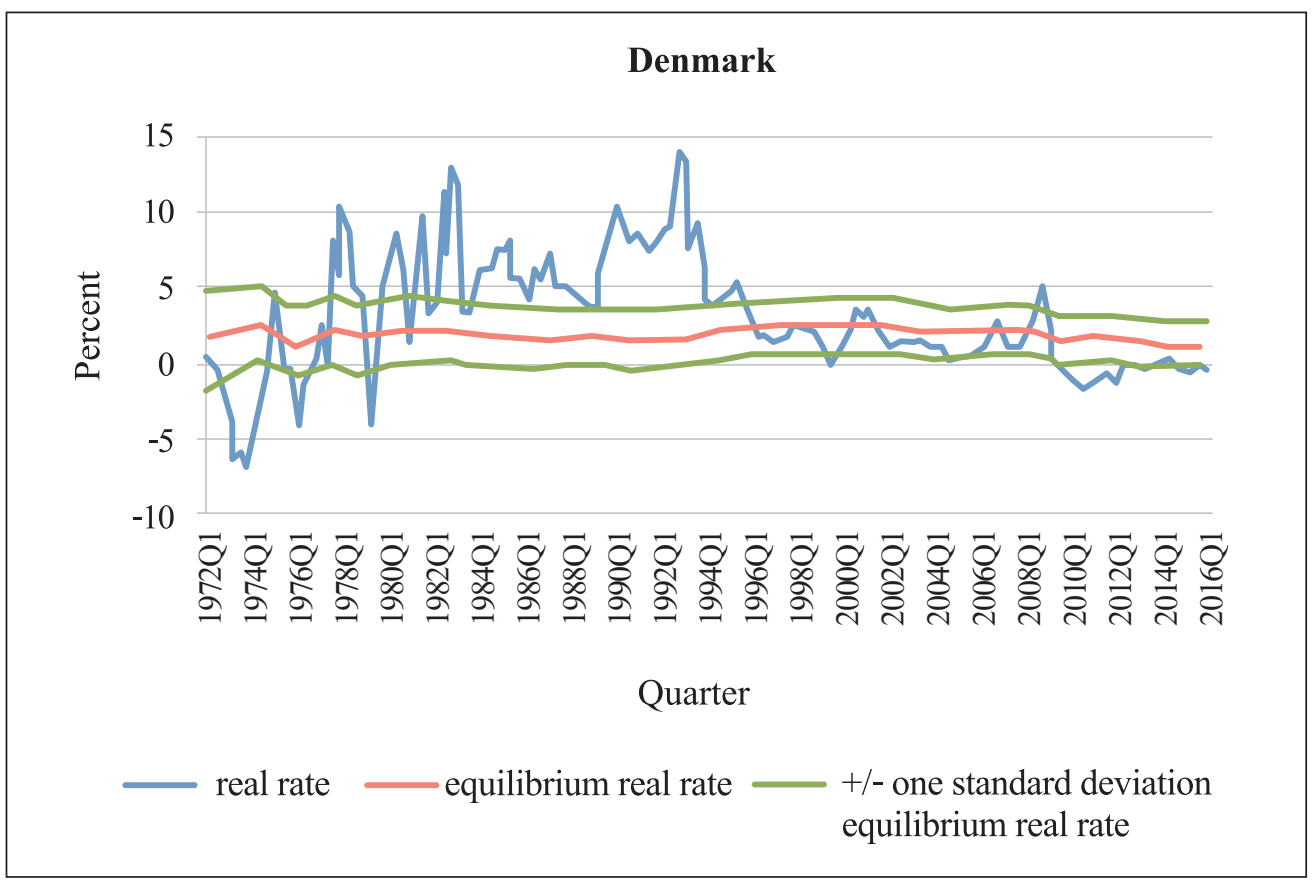




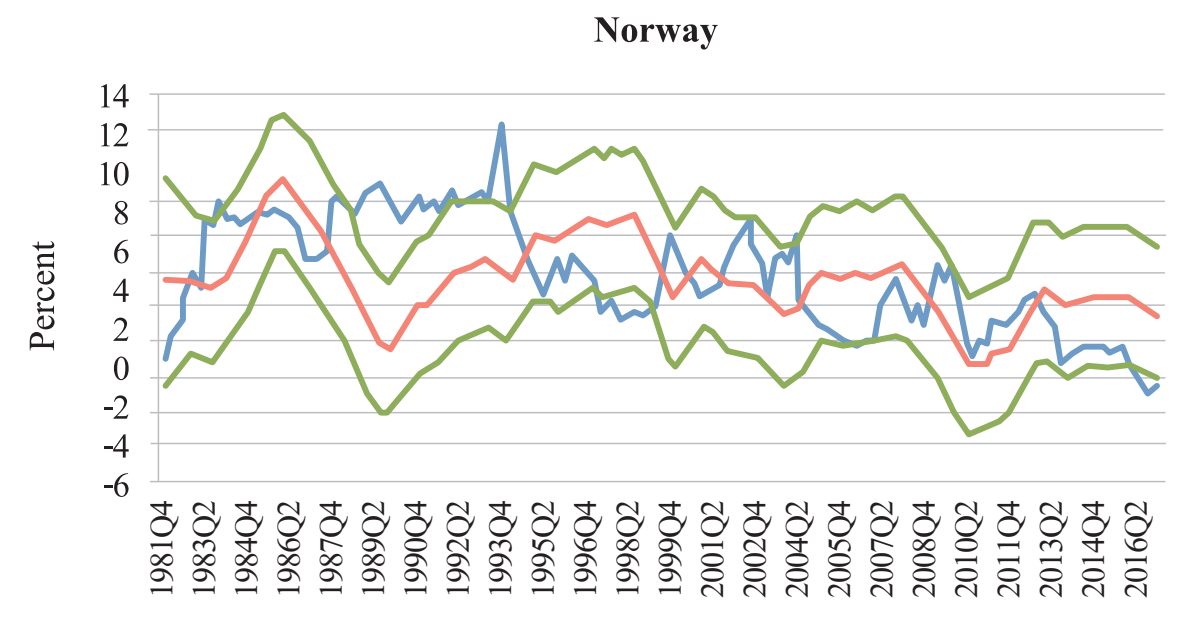

Quarter

real rate $\_$equilibrium real rate +/- one standard deviation equilibrium real rate

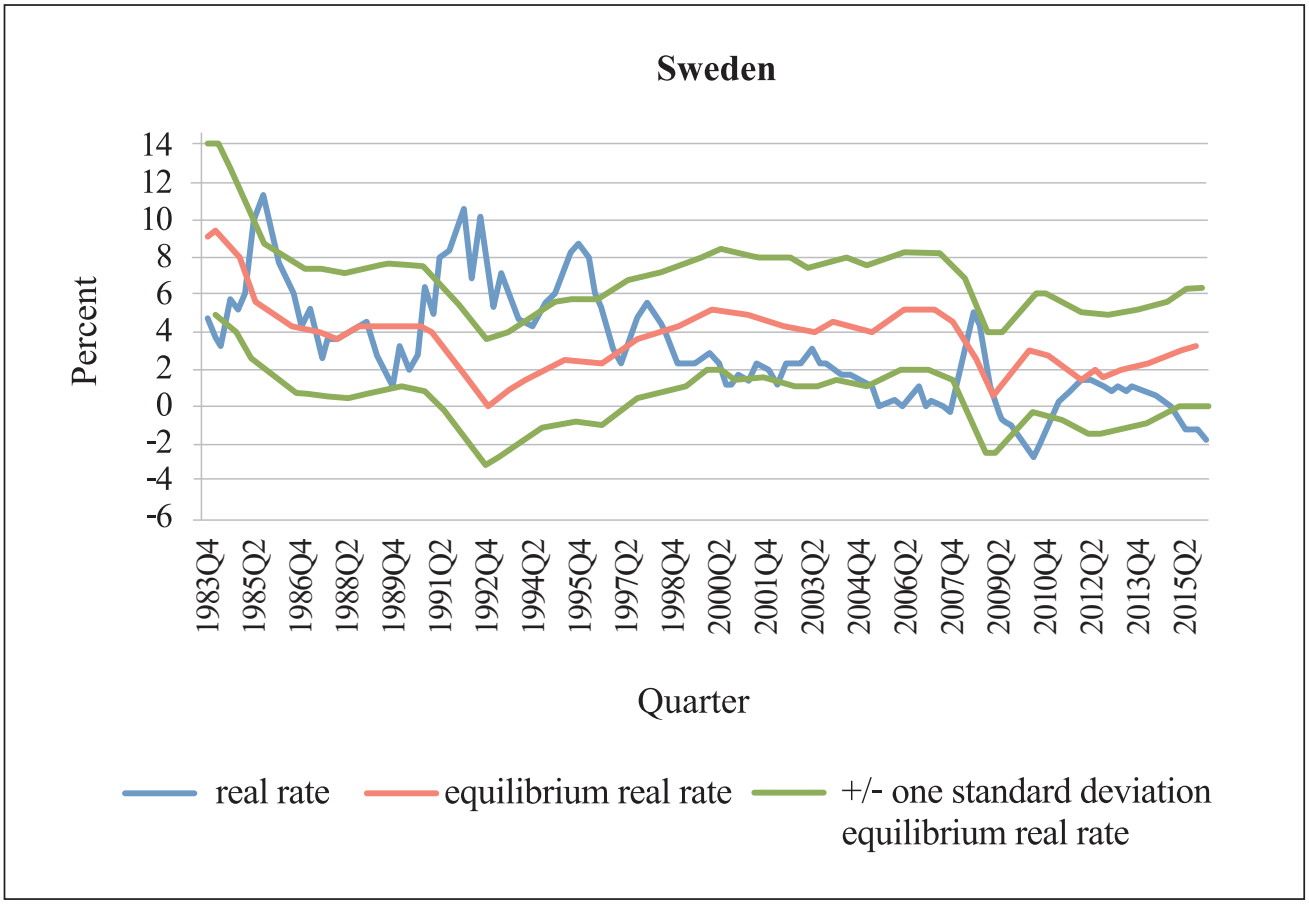



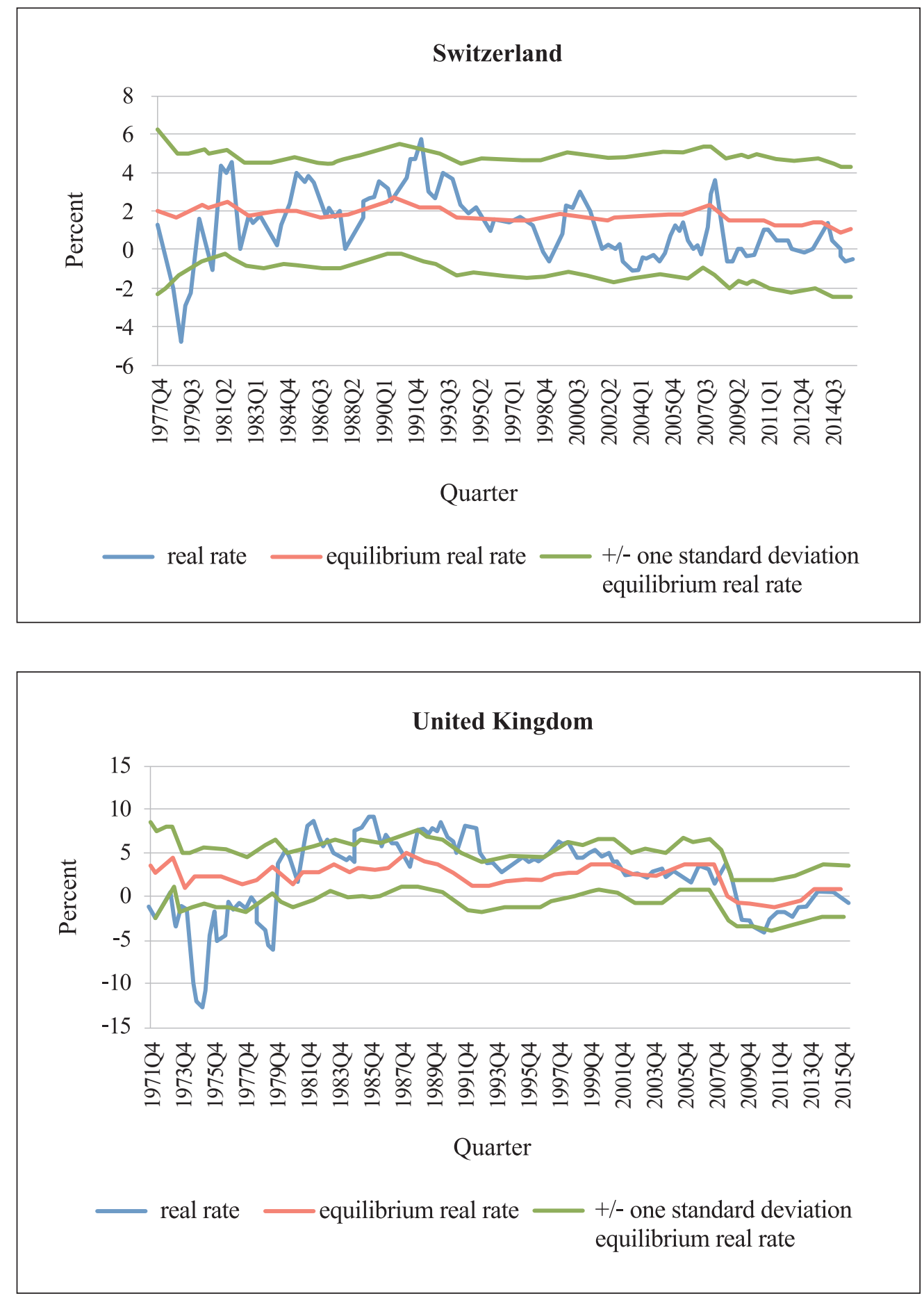
Figure 7. Ex-post real rates and two-sided equilibrium estimates
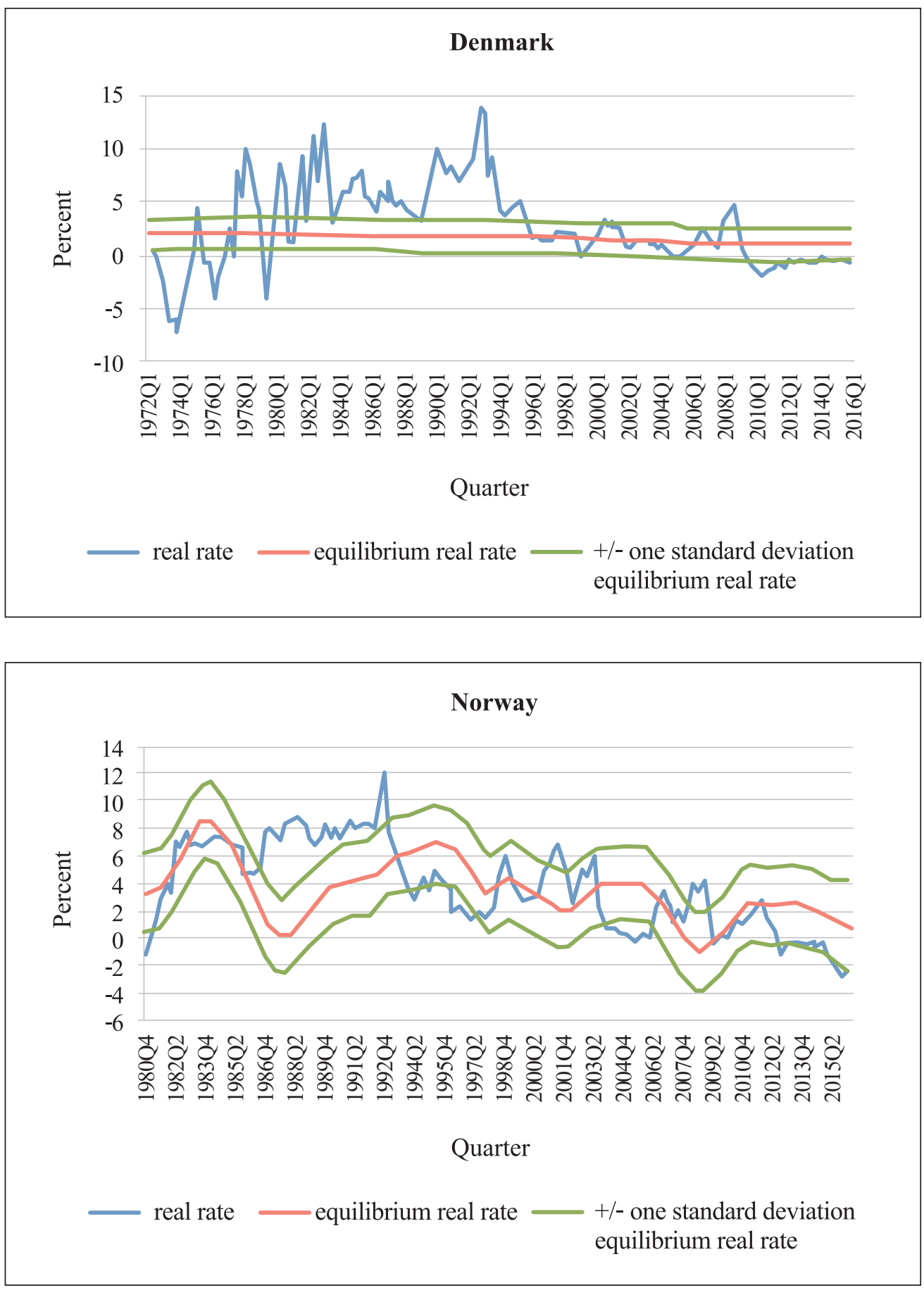

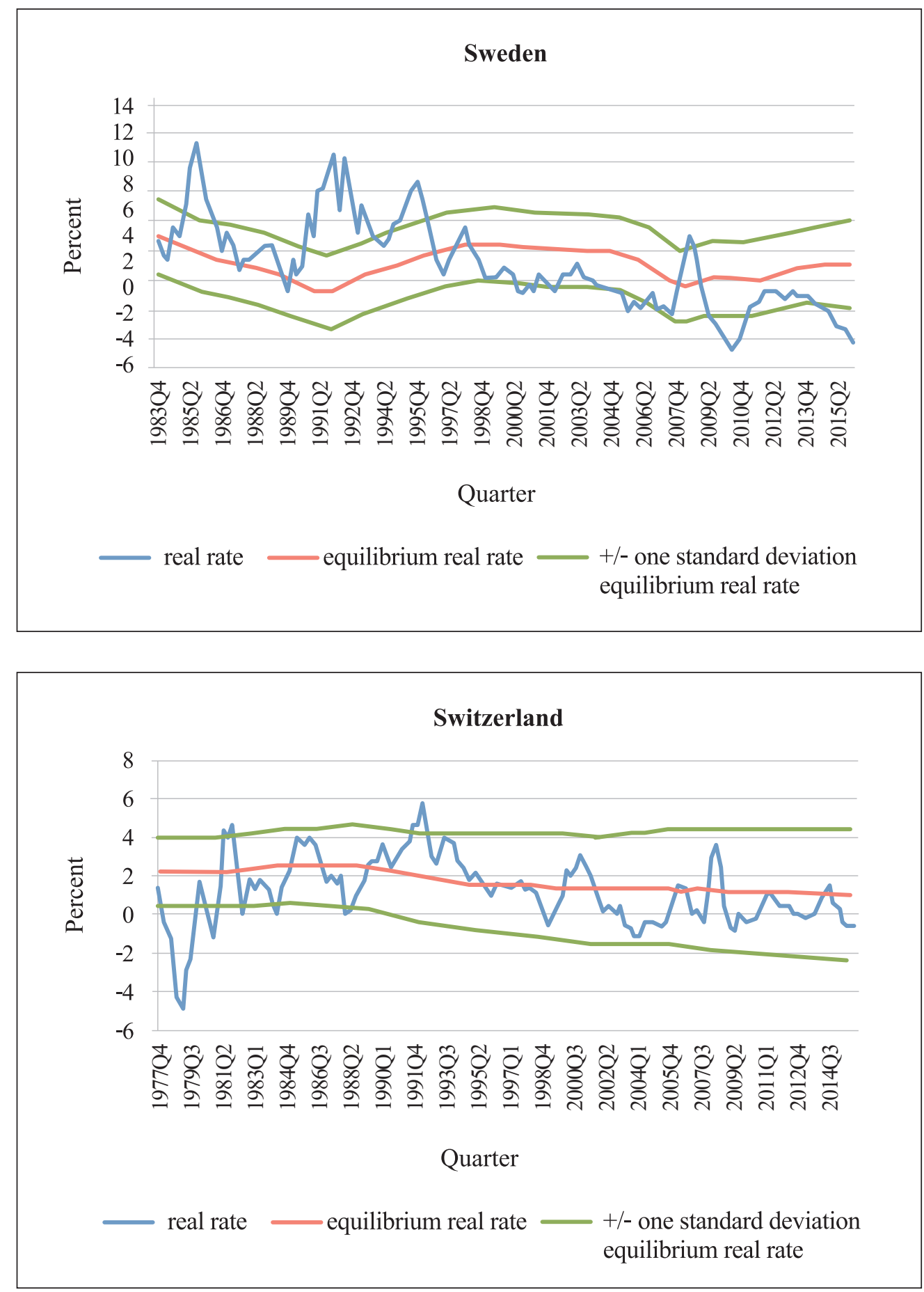


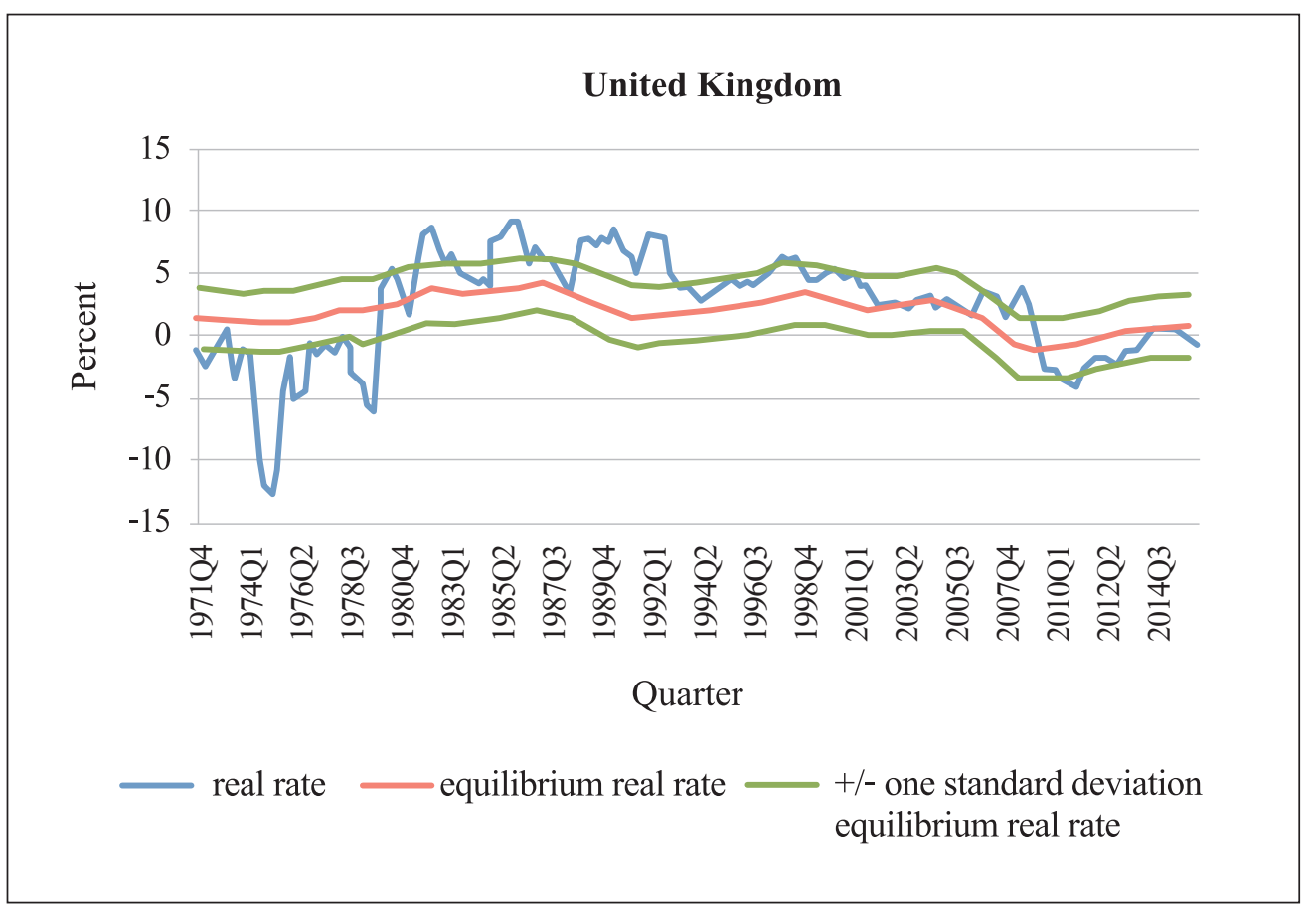

\section{Conclusions}

In this paper, the question as to whether five non-EMU European countries face secular stagnation has been answered. Knowing the answer has important implications for European policymakers. While secular stagnation does not seem to be a problem for the euro area as a whole (Beyer and Wieland 2015, Belke and Klose 2017), permanently lower growth rates in other European countries may lead to a process of disintegration, at least in economic terms.

However, the results do not point to secular stagnation in any of the countries under investigation. Therefore, no additional measures should be undertaken by national policymakers to stimulate economic growth. This especially holds for any additional monetary policy expansions. Indeed, today, all central banks in the non-EMU European countries adopt expansionary measures, as shown by the very low policy rates in Figure 1. Moreover, some of them have even used additional unconventional monetary policy measures, such as the asset purchase program of the Bank of England; the policy of 
negative central bank policy and deposit rates in Sweden, Denmark, and Switzerland; and the policy of a lower bound on the exchange rate in Switzerland. But these measures seem to be reasonable, especially against the background of an even more expansionary monetary policy currently adopted by the ECB.

Moreover, the analysis reveals that there is no need for further short-term economic stimulus, especially via demand-side policies, e.g., by economic stimulus packages. While this could be one way to get out of a situation like secular stagnation, it may face longer-term problems because public debt increases with this policy, making the debt problem even more severe in the future.

It may be that while there is currently no problem of secular stagnation in the nonEMU European countries, they will face long-term secular stagnation in the future. However, this problem would be a result of inappropriate supply-side policies in these countries (Crafts 2015). Therefore, it is important to set the course with respect to necessary supply-side reforms today. One possible way to achieve this is to reduce deregulation in the product and labor markets and thus boost productivity.

But the result of no secular stagnation is also driven by rather uncertain estimates of the equilibrium real rate. In-depth work is needed in this respect to generate more reliable estimates of this unobserved variable. Possible determinants influencing the equilibrium real rate via aggregate savings, aggregate investments, or both have been discussed in this paper. However, they are not explicitly modeled in the Laubach-Williams framework. Instead, these determinants should show up in the unobserved variable of additional factors $\left(z_{t}\right)$, without knowing its exact influence on the equilibrium real rate. The influence of the possible determinants has not been investigated empirically to date and we leave this for further research. There is only limited empirical testing in this respect. For example, Juselius et al. (2016) added a financial cycle to the standard Laubach-Williams model for the US and found that the equilibrium real rate is higher in this setting. But they do not model the financial cycle, which is a way to determine the "private and public debt levels," which directly influence the equilibrium real rate, as the discussion in this paper suggests. Therefore, further research is needed for this and all other determinants in order to provide more reliable estimates of the equilibrium real rate and to make more robust inferences about secular stagnation. 


\section{References}

Barnes, Sebastian, Romain Bouis, Philippe Briard, Sean Dougherty and Mehmet Eris. "The GDP Impact of Reforms - A Simple Simulation Framework." OECD Economics Department Working Paper No. 834 (2013).

Belke, Ansgar and Jens Klose. "Modifying Taylor-Reaction Functions in the Presence of the Zero-Lower-Bound - Evidence for the ECB and the Fed." Economic Modelling 35 (2013): 515-27.

Belke, Ansgar and Jens Klose. "Equilibrium Real Interest Rates and Secular Stagnation: An Empirical Analysis for Euro Area Member Countries." forthcoming Journal of Common Market Studies (2017).

Beyer, Robert C.M. and Volker Wieland. "Schätzung des mittelfristigen Gleichgewichtszinses in den Vereinigten Staaten, Deutschland und dem Euro-Raum mit der LaubachWilliams-Methode.” SVR-Working Paper No. 03/2015 (2015).

Blanchard, Olivier, Giovanni Dell'Ariccia, and Paolo Mauro. "Rethinking Macroeconomic Policy." IMF Staff Position Note 10/03 (2010).

Blanchard, Olivier and Lawrence Summers. "Hysteresis and the European Unemployment Problem." in NBER Macroeconomics Annual 1 (1986): 15-78.

Browning, Martin and Thomas F. Crossley. "The Life-Cycle Model of Consumption and Savings." Journal of Economic Perspectives 15 (3) (2001): 3-22.

Caballero, Ricardo J. and Emmanuel Farhi. "On the Role of Safe Assets Shortages in Secular Stagnation." in "Secular Stagnation: Facts, Causes and Cures" VoxEU (2014): 111-22.

Clark, Todd E. and Sharon Kozicki. "Estimating Equilibrium Real Interest Rates in Real Time." The North American Journal of Economics and Finance 16(3) (2005): 395-413.

Crafts, Nicolas. "Is Secular Stagnation the Future for Europe?" The University of Warwick Working Paper Series No. 225 (2015).

Draghi, Mario. "Unemployment in the Euro Area." Speech at the Annual Central Bank Symposium in Jackson Hole, 22. August 2014.

Garnier, Julien and Bjorn-Roger Wilhelmsen. "The Natural Rate of Interest and the 
Output Gap in the Euro Area: A Joint Estimation." Empirical Economics 36 (2009): 297319.

Glaeser, Edward L. "Secular Joblessness" in "Secular Stagnation: Facts, Causes and Cures.", VoxEU (2014): 69-82.

Gordon, Robert J. “The Turtle's Progress: Secular Stagnation Meets the Headwinds.” in "Secular Stagnation: Facts, Causes and Cures", VoxEU (2014): 47-60.

Gros, Daniel "Investment as the Key to Recovery in the Euro Area." CEPS Policy Briefs 18. November 2014, Brussels.

Hamilton, James D., Ethan S. Harris, Jan Hatzius and Kenneth D. West. "The Equilibrium Real Funds Rate: Past, Present and Future.” NBER Working Paper No. 21476 (2015).

Hansen, Alvin H. "Economic Progress and Declining Population Growth." American Economic Review 29(1) (1939): 1-15.

Hodrick, Robert J. and Edward C. Prescott. "Post-War Business Cycles: An Empirical Investigation.” Journal of Money, Credit and Banking 29 (1997): 1-16.

Kathryn Holston, Thomas Laubach and John C. Williams. "Measuring the Natural Rate of Interest: International Trends and Determinants.” FRBSF Working Paper 2016-11 (2016).

Jimeno, Juan F., Frank Smets and Jonathan Yiangou. "Secular Stagnation: A view from the Eurozone." in "Secular Stagnation: Facts, Causes and Cures", VoxEU (2014): 15364.

Juselius, Mikael, Claudio Borio, Piti Disyata and Matthias Drehmann. "Monetary Policy, the Financial Cycle and Ultra-low Interest Rates.” BIS Working Paper No. 569 (2016).

Kiley, Michael T. "What Can the Data Tell Us About the Equilibrium Real Interest Rate?" Finance and Economics Discussion Series 2015-077 Board of Governors of the Federal Reserve System (2015).

Koo, Richard C. "Balance Sheet Recession is the Reason for Secular Stagnation." in "Secular Stagnation: Facts, Causes and Cures", VoxEU (2014): 131-42.

Krugman, Paul. "Four Observations on Secular Stagnation." in "Secular Stagnation: Facts, Causes and Cures", VoxEU (2014): 61-68. 
Laubach, Thomas and John C. Williams. "Measuring the Natural Rate of Interest." The Review of Economics and Statistics 85(4) (2003): 1063-70.

Laubach, Thomas and John C. Williams "Measuring the Natural Rate of Interest Redux." FRBSF Working Paper 2015-16 (2015).

Mesonnier, Jean S. and Jean P. Renne. "A Time-Varying 'Natural' Rate of Interest for the Euro Area." European Economic Review 51 (2007): 1768-84.

Mokyr, Joel. "Secular Stagnation? Not in your life." in "Secular Stagnation: Facts, Causes and Cures", VoxEU (2014): 83-90.

Stock, James H. "Unit Roots, Structural Breaks and Trends." in Robert Engle and Dan McFadden "Handbook of Econometrics" 4 (1994): 2739-2841.

Stock, James H. and Mark W. Watson. "Median Unbiased Estimator of Coefficient Variance in a Time-Varying Parameter Model." Journal of the American Statistical Association 93 (1998): 349-58.

Summers, Lawrence. "U.S. Economic Prospects: Secular Stagnation, Hysteresis, and the Zero Lower Bound.” Business Economics, 49(2) (2014a): 65-73.

Summers, Lawrence. "Reflections on the "New Secular Stagnation Hypothesis." in "Secular Stagnation: Facts, Causes and Cures", VoxEU (2014b): 27-38.

Summers, Lawrence. "Low Equilibrium Real Rates, Financial Crisis and Secular Stagnation.", in "Across the Great Divide: New Perspectives on the Financial Crisis" (2014c): 37-50.

Trehan, Bharat and Tao Wu. "Time Varying Equilibrium Real Rates and Monetary Policy Analysis.” FRBSF Working Paper 2004-10 (2004).

Teulings, Coen and Richard Baldwin. "Secular Stagnation: Facts, Causes and Cures.", VoxEU (2014). 